УДК: 619:576.895.1:636.2

doi: $10.36359 /$ scivp.2019-20-2.36

\title{
ПОРІВНЯЛЬНА ОЦІНКА ПРЕПАРАТІВ НА ОСНОВІ ФІПРОНІЛУ ЗА ІНВАЗІЇ СОБАК І КОТІВ ЕКТОПАРАЗИТАМИ
}

\author{
О. Л. Тішин, д-р вет. наук, с. н.с., \\ Р. В. Хом'як, с. н. с., \\ Ж. М. Періг, канд. вет. наук, с. н.с.
}

\begin{abstract}
Державний науково-дослідний контрольний інститут ветеринарних препаратів
та кормових добавок

вул. Донецька, 11, м. Львів, 79019, Україна
\end{abstract}

\begin{abstract}
У статті наведено дані щзодо ефективності нового вітчизняного протипаразитарного препарату «Профілайн спот-он для собак та котів (краплі для зовнішнього застосування)》 у порівнянні з препаратом "Інсектостоп для собак та котів (рідина нашкірна)» (діюча речовина препаратів фіпроніл) на собаках $і$ котах різних порід при застосуванні їх із профілактичною та лікувальною метою за ектопаразитарних інвазіях. Інтенсивність інвазії блохами та вошами визначали шляхом підрахунку ектопаразитів

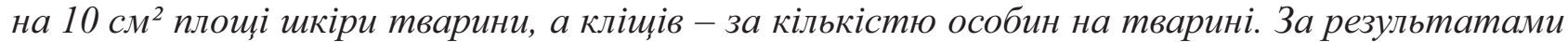
проведених досліджень встановлено, стійку інвазованість усіх залучених для дослідження 17 собак $і 15$ котів блохами. У 14 собак та 8 котів виявлена змімана інвазія блохами і вошами i y 7 собак $i 4$ котів, поряд із змішаною інвазією виявлені ураження шкірного покриву іксодовими кліщами Ixоdеs ricinus. При иьому інтенсивність інвазї̈ у собак та котів блохами становила від 5 до 8 особин та вошами - від 1 до 3 особин на 10 см $^{2}$ площі шкіри тварини, а інвазованість кліщами становила 2-7 особин на тілі тварини. На 2, 5, 7 доби після лікування, на оброблених тваринах виявлялись мертві блохи, воші та кліщі, а на 10 i 30 доби ектопаразитів на тілі тварин не було виявлено. Під час лікування ускладнень чи змін у клінічному стані не спостерігалось, а екстенсефективність (ЕE) препаратів за виробничих випробувань за ураження собак та котів блохами, вошами та кліщами становила $100 \%$.
\end{abstract}

Ключові слова: СОБАКИ, КОТИ, ЕКТОПАРАЗИТИ, БЛОХИ, ВОЩІ, КЛІЩІ, ФІПРОНІЛ, ЕКСТЕНСИВНІСТЬ ІНВАЗІЇ, ЕКСТЕНСЕФЕКТИВНІСТЬ.

В останні роки кількість домашніх та безпритульних тварин значно зросла, що в свою чергу призвело до значного поширення інвазійних захворювань, зокрема ектопаразитозів. Найбільш поширеними збудниками ектопаразитозів собак та котів є блохи (Siphonapteridae, Ctenocephalus canis (у собак), Ctenocephalus felis (у котів), воші (ряд Siphunculata, родини Linognathidae, Linognathus setotus), паразитоформні кліщі (Dermacentor spp., Rhipicephalus spp., Ixodes spp.). Збудники даної групи захворювань є переносниками й носіями вірусних, бактеріальних, протозойних, рикетсіозних захворювань та мікозів тварин і людей. Таким чином, своєчасна діагностика, лікування та профілактика ектопаразитозів серед домашніх та безпритульних тварин, насамперед у великих містах, має велике значення.

Успішна боротьба з ектопаразитарними хворобами домашніх тварин (собак і котів) можлива лише за наявності високоефективних ветеринарних лікарських засобів. Забезпечення власників тварин необхідним асортиментом ефективних та недорогих засобів боротьби 3 ектопаразитами хворобами, у зручних для застосування формах - шлях до благополуччя щодо цих захворювань. Досягти цього можна лише за умови розробки та виробництва високоефективних дешевих вітчизняних лікарських засобів, чи вдосконалення вже відомих ветеринарних препаратів. 
Терапевтична ефективність (хіміотерапевтичних засобів для лікування ектопаразитозів) залежить у першу чергу від хімічної активності діючої речовини. Проте встановлено, що суттєве значення також мають лікарська форма та технологія виготовлення препаратів, їх фізичний стан, властивості складових компонентів і шляхи введення в організм.

Протиектопаразитарні препарати належать до різних класів сполук, і як правило, ефективні проти вузького кола збудників, що спонукає власників тварин застосовувати для лікування і профілактики десятки препаратів, далеко не бездоганних у дії на організм тварини та небезпечних в екологічному аспекті. Тому спеціалістів завжди цікавила можливість створення і застосування лікарських засобів з широким спектром дії [1].

В останні десятиріччя виробниками було запропоновано ряд засобів, одним з таких препаратів $\epsilon$ «Профілайн спот он для собак та котів (краплі для зовнішнього застосування)» який застосовується з лікувально-профілактичною метою за ектопаразитозів собак і котів на всіх стадіях розвитку паразитів.

Метою нашої роботи було вивчення терапевтичної ефективностіі препарату «Профілайн спот он для собак та котів (краплі для зовнішнього застосування)» та референспрепарату «Інсектостоп для собак та котів (рідина нашкірна)» на основі фіпронілу у рекомендованих дозах на собаках і котах різних порід при застосуванні їх із профілактичною та лікувальною метою при ектопаразитарних інвазіях.

Діюча речовина препаратів фіпроніл відноситься до групи фенілпіразолів та ефективно діє при безпосередньому контакті на кліщів, вошей, бліх та мух, які паразитують на шкірі тварин. Вона блокує передачу нервових імпульсів гангліозними периферичними нервами, в результаті чого наступає параліч та загибель паразита.

Матеріали і методи. Для досліджень було залучено 17 собак та 15 котів різних порід. Проводили дослідження зажиттєвої діагностики ектопаразитозів та визначали кількість ектопаразитів. Ідентифікацію збудників ектопаразитозів проводили мікроскопічним методом.

Дози препаратів з розрахунку на масу тіла тварини

Таблиия 1

\begin{tabular}{|c|c|c|}
\hline Маса тіла тварини, кг & Доза препарату (мл/масу тіла тварини) & Кількість ампул-крапельниць, шт \\
\hline \multicolumn{3}{|c|}{ Досліджуваний та референс-препарат } \\
\hline \multicolumn{3}{|c|}{ Собаки різних порід } \\
\hline 4-10 кг & 0,8 & 1 \\
\hline $10-20$ кг & 1,6 & 2 \\
\hline $20-40$ кг & 2,4 & 3 \\
\hline більше 40 кг & 3,2 & 4 \\
\hline \multicolumn{3}{|c|}{ Досліджуваний препарат «Профілайн спот-он для собак та котів (краплі для зовнішнього застосування)» } \\
\hline \multicolumn{3}{|c|}{ Коти різних порід (віком від 8 тижнів, вагою від 2 кг) } \\
\hline $2-4$ & 0,6 & 1 \\
\hline $4-8$ & 1,2 & 2 \\
\hline \multicolumn{3}{|c|}{ Референс-препарат «Інсектостоп для собак та котів (рідина нашкірна)» } \\
\hline \multicolumn{3}{|c|}{ Коти різних порід } \\
\hline \multicolumn{3}{|c|}{ 0,8 мл препарату (1 ампула) на тварину } \\
\hline
\end{tabular}

Інтенсивність інвазії визначали шляхом підрахунку ектопаразитів на $10 \mathrm{~cm}^{2}$ площі шкіри тварини. Хворих тварин поділили на дві групи: дослідну - наносили дослідний препарат і контрольну - наносили референс- препарат [2]. Тваринам дослідних (10 собак і 10 котів) та контрольних груп (7 собак і 5 котів) були створені ідентичні умови догляду і утримання. До, під час і після лікування проводили клінічне обстеження тварин. Дослідним і контрольним тваринам препарати наносили індивідуально, зовнішньо, безпосередньо на шкіру, у місця недоступні для злизування: собакам - у ділянку холки та вздовж хребта, котам - у ділянку потилиці, одноразово (згідно табл. 1). 
Через 2. 5, 7, 9 і 30 діб після лікування, проводили облік результатів досліджень на основі оглядів оброблених тварин, підрахунку живих ектопаразитів на них та визначали екстенсивність інвазії після лікування та екстенсефективність препарату.

Екстенсивність інвазії (ЕI) визначали як відношення кількості заражених тварин до кількості відібраних, виражене у відсотках. Інтенсивність інвазії (II) визначали за кількістю ектопаразитів на $10 \mathrm{~cm}^{2}$ площі шкіри тварини. Екстенсефективність (ЕЕ) препарату розраховували за кількістю оброблених тварин у відсотках, які повністю звільнилися від паразитів.

Результати й обговорення. В результаті проведення клінічного огляду хворих собак $\mathrm{i}$ котів, було встановлено почервоніння, запалення шкіри, добре помітний рефлекс свербежу, на шкірі папули, луски. Помітні місця облисіння. Шкіра груба, тріскається [3].

При візуальному дослідженні встановлено стійку інвазованість усіх собак блохами, у 14 собак виявлена змішана інвазія блохами $і$ вомами і у 7 собак поряд із змішаною інвазією блохами і вошами виявлені ураження шкірного покриву іксодовими кліщами Ixodes ricinus.

При візуальному дослідженні виявлено інвазованість усіх котів блохами, у 8 котів встановлено змішану інвазію блохами і вошами і у 4 котів поряд із змішаною інвазією блохами i вошами виявлено ураження шкірного покриву іксодовими кліщами Ixodes ricinus.

При цьому інтенсивність інвазії у собак та котів блохами становила від 5 до 8 особин та

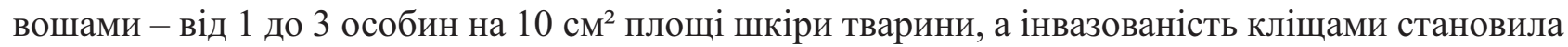
2-7 особин на тілі тварини. На 2, 5, 7 добу після лікування, на оброблених тваринах виявлялись мертві блохи, воші та кліщі. На 10 добу бліх, вошей та кліщів на тілі тварин не виявлено. На 30 добу бліх, вошей та кліщів на тілі тварин також не було виявлено.

Результати дослідження терапевтичної ефективності препаратів при ектопаразитарних інвазіях собак та котів за їх обробки подані у таблицях 2 та 3. Під час лікування і протягом клінічного спостереження за дослідними та контрольними тваринами, після застосування препаратів ніяких ускладнень чи змін у клінічному стані не спостерігалось.

Таблиия 2

Вивчення на собаках терапевтичної ефективності препарату «Профілайн спот он для собак та котів (краплі для зовнішнього застосування)» та референс-препарату «Інсектостоп для собак та котів (рідина нашкірна)»

\begin{tabular}{|c|c|c|c|c|}
\hline \multirow{3}{*}{ Група тварин } & \multirow{3}{*}{$\begin{array}{c}\text { Вид ектопаразитів: } \\
\text { блохи, воші, } \\
\text { іксодові кліщі }\end{array}$} & \multicolumn{3}{|c|}{ Заражено } \\
\hline & & \multicolumn{2}{|c|}{ До обробки } & \multirow{2}{*}{$\begin{array}{c}\text { Після обробки } \\
\text { ЕЕ препарату (\%) }\end{array}$} \\
\hline & & EI, \% & II & \\
\hline $\begin{array}{c}\text { Дослідна група } \\
\text { (10 тварин) }\end{array}$ & $\begin{array}{l}\text { Ctenocephalus canis } \\
\text { Linognathus setotus } \\
\text { Ixodes ricinus }\end{array}$ & 100 & $\begin{array}{l}5-8 \\
1-3 \\
2-7\end{array}$ & $\begin{array}{c}100 \\
\text { (не виявлено) }\end{array}$ \\
\hline $\begin{array}{c}\text { Контрольна група } \\
\text { (7 тварин) }\end{array}$ & $\begin{array}{c}\text { Ctenocephalus canis, } \\
\text { Linognathus setotus } \\
\text { Ixodes ricinus }\end{array}$ & 100 & $1-8$ & $\begin{array}{c}100 \\
\text { (не виявлено) }\end{array}$ \\
\hline
\end{tabular}

Таблиця 3

Вивчення на котах терапевтичної ефективності препарату «Профілайн спот он для собак та котів (краплі для зовнішнього застосування)» та референс-препарату «Інсектостоп для собак та котів (рідина нашкірна)»

\begin{tabular}{|c|c|c|c|c|}
\hline \multirow{3}{*}{ Група тварин } & \multirow{3}{*}{$\begin{array}{c}\text { Вид ектопаразитів: } \\
\text { блохи, воші, } \\
\text { іксодові кліщі } \\
\end{array}$} & \multicolumn{3}{|c|}{ Заражено } \\
\hline & & \multicolumn{2}{|c|}{ До обробки } & \multirow{2}{*}{$\begin{array}{c}\text { Після обробки } \\
\text { EЕ препарату (\%) }\end{array}$} \\
\hline & & EI, \% & II & \\
\hline $\begin{array}{c}\text { Дослідна група } \\
\text { (10 тварин) }\end{array}$ & $\begin{array}{c}\text { Ctenocephalus canis } \\
\text { Linognathus setotus } \\
\text { Ixodes ricinus }\end{array}$ & 100 & $\begin{array}{l}5-8 \\
1-3 \\
2-7\end{array}$ & $\begin{array}{c}100 \\
\text { (не виявлено) }\end{array}$ \\
\hline $\begin{array}{c}\text { Контрольна } \\
\text { група } \\
\text { (5 тварин) } \\
\end{array}$ & $\begin{array}{c}\text { Ctenocephalus canis, } \\
\text { Linognathus setotus } \\
\text { Ixodes ricinus }\end{array}$ & 100 & $\begin{array}{l}1-8 \\
1-8 \\
2-7\end{array}$ & $\begin{array}{c}100 \\
\text { (не виявлено) }\end{array}$ \\
\hline
\end{tabular}


Екстенсефективність (ЕЕ) препарату «Профілайн спот он для собак та котів (краплі для зовнішнього застосування)» та референс-препарату «Інсектостоп для собак та котів (рідина нашкірна)» за виробничих випробувань за ураження собак та котів блохами, вошами та кліщами становила $100 \%$.

\title{
В И С Н О В К И
}

1. На основі проведених досліджень препарату «Профілайн спот он для собак та котів (краплі для зовнішнього застосування)» встановлено, що він добре переноситься собаками та котами і не дає ніяких побічних ефектів і змін у клінічному стані тварин.

2. Клінічні дослідження показали добру активність препарату як засобу з широким спектром дії проти бліх, вошей та кліщів.

Перспективи подальших досліджень. Планується проведення дослідження проб підстилки 3 вольєрів у яких утримувались оброблені тварини на наявність личинок і німф ектопаразитів.

\section{COMPARATIVE EVALUATION OF FIPRONIL BASED PREPARATIONS FOR INVASIONS OF DOGS AND COTS WITH ECOPARAZITES}

\author{
O. L. Tishyn, R. V. Khomiak, Zh. M. Perih
}

State Scientific Research Control Institute of Veterinary Medicinal Products and Fodder Additives

11, Donetska str., Lviv, 79019, Ukraine

\section{S U M M A R Y}

The article presents data on the effectiveness of the new domestic anti-parasitic drug "Profile spot for dogs and cats (drops for external use)" compared to the drug "Insectostope for dogs and cats (liquid of the skin)" (active ingredient of drugs fipronil) in dogs and cats of different breeds in the use of them with a preventive and curative purpose for ectoparasit invasions. Extensiveness of invasion (EI) was defined as the ratio of the number of infected animals to the number of selected, expressed in percents. The intensity of invasion (II) with fleas and lice was determined by counting ectoparasites at $10 \mathrm{~cm}^{2}$ of the skin of the animal's skin, and ticks by the number of individuals per animal. Extensive efficacy (EE) of the preparation was calculated based on the number of treated animals in percentages, which were completely exempt from parasites. According to the results of the conducted researches, stable invasion of all $17 \mathrm{dogs}$ and 15 cats fleas involved in the study was established. In 14 dogs and 8 cats, a mixed invasion of fleas and lice and 7 dogs and 4 cats was revealed, along with mixed infestation, skin lesions and Ixodes ricinus mites were detected. At the same time, the intensity of invasion in dogs and cats by fleas ranged from 5 to 8 individuals and lice from 1 to 3 individuals per $10 \mathrm{~cm}^{2}$ of animal skin area, and the ticks infestation was 2-7 individuals per animal's body. The experimental and control groups of animals were dosed individually, once. In doses according to leaflets tabs. At 2, 5, 7 days after treatment, dead animals, lice and mites were found on treated animals, and 10 and 30 days of ectoparasites on the animal's body were not detected. During the treatment of complications or changes in clinical condition, no extraneous efficacy (EE) of preparations for manufacturing tests for the defeat of dogs and cats by fleas, lice and ticks was $100 \%$.

Keywords: DOGS, COATS, ECOPARAZITES, BLOYS, HEADS, CLIPS, FIPRONIL, EXTENSION OF INVASIONS, EXTENSIVE EFFICIENCY. 


\title{
СРАВНИТЕЛЬНАЯ ОЦЕНКА ПРЕПАРАТОВ НА ОСНОВЕ ФИПРОНИЛА ПРИ ИНВАЗИИ СОБАК И КОШЕК ЭКТОПАРАЗИТОЗАМИ
}

\author{
А. Л. Тишин, Р. В. Хомяк, Ж. Н. Периг
}

Государственный научно-исследовательский контрольный институт ветеринарных препаратов и кормовых добавок

ул. Донецкая, 11, г. Львов, 79019, Украина

\section{А Н Н О Т А ЦИ Я}

В статье приведены данные по эффективности нового отечественного противопаразитарного препарата «Профилайн спот-он для собак и кошек (капли для наружного применения)» по сравнению с препаратом «Инсектостоп для собак и кошек (жидкость накожная)» (действующее вещество препаратов фипронил) на собаках и кошках разных пород при применении их с профилактической и лечебной целью при эктопаразитарных инвазиях. Интенсивность инвазии блохами и вшами определяли путем

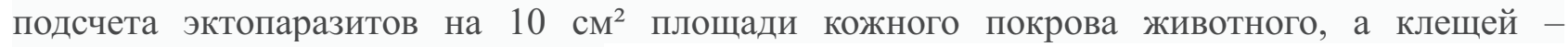
количеством особей на животном. По результатам проведенных исследований установлено, устойчивую инвазованость всех привлеченных для исследования 17 собак и 15 кошек блохами. У 14 собак и 8 кошек обнаружена смешанная инвазия блохами и вшами и у 7 собак и 4 кошек, наряду со смешанной инвазией выявлены поражения кожного покрова иксодовыми клещами Ixodes ricinus. При этом интенсивность инвазии у собак и кошек блохами составляла от 5 до 8 особей и вшами - от 1 до 3 особей на $10 \mathrm{~cm}^{2}$ площади кожи животного, а инвазованость клещами составляла 2-7 особей на теле животного. На 2, 5, 7 сутки после лечения, на обработанных животных выявлялись мертвые блохи, вши и клещи, а на 10 и 30 сутки эктопаразитов на теле животных не было обнаружено. Во время лечения осложнений или изменений в клиническом состоянии не наблюдалось, а єкстенсєффективность (ЭЭ) препаратов при производственных испытаниях при инвазии собак и кошек блохами, вшами и клещами составляла $100 \%$.

Ключевые слова: СОБАКИ, КОШКИ, ЭКТОПАРАЗИТЫ, БЛОХИ, ВЩИ, КЛЕЩИ, ФИПРОНИЛ, ЭКСТЕНСИВНОСТЬ ИНВАЗИИ, ЭКСТЕНСЭФФЕКТИВНОСТЬ

\section{Л I T E P A T Y P A}

1. Кузьмін А. А. Фармакотерапія у ветеринарній медицині: клінічні та етичні аспекти / А. А. Кузьмін // Проблеми ветеринарного обслуговування дрібних домашніх тварин. - К., 1998.

2. World Association for the Advancement of Veterinary Parasitology (W.A.A.V.P.) second edition: Guidelines for evaluating the efficacy of parasiticides for the treatment, prevention and control of flea and tick infestations on dogs and cats. $-14 \mathrm{p}$.

3. Галат В.Ф. Паразитологія та інвазійні хвороби тварин / В.Ф. Галат, А. В. Березовський, М. П. Прус, Н. М. Сорока. - К., Урожай, 2009. - 363 с.

\section{References}

1. Kuz'min A. A. Farmakoterapiya u veterynarniy medytsyni: klinichni ta etychni aspekty / A. A. Kuz'min // Problemy veterynarnoho obsluhovuvannya dribnykh domashnikh tvaryn. K., 1998. (in Ukrainian). 
2. World Association for the Advancement of Veterinary Parasitology (W.A.A.V.P.) second edition: Guidelines for evaluating the efficacy of parasiticides for the treatment, prevention and control of flea and tick infestations on dogs and cats. $-14 \mathrm{p}$.

3. Halat V. F. Parazytolohiya ta invaziyni khvoroby tvaryn / V. F. Halat, A. V. Berezovs'kyy, M. P. Prus, N. M. Soroka. - K., Urozhay, 2009. - 363 s. (in Ukrainian).

Рецензент - І. Д. Юськів, д. вет. н., професор кафедри паразитології та іхтіопатології ЛНУВМБ імені С. З. Гжицького.

doi: 10.36359/scivp.2019-20-2.37

\title{
"DEMOGED-FORTE" VETERINARY MEDICINAL PRODUCT IN COMBATING ECTOPARAZITOSIS IN DOGS AND CATS
}

\author{
Enciu Valeriu \\ State Agrarian University of Moldova. \\ 42, Mirceşti Street, Chişinău, MD 2049, Moldova
}

Parasitic arachnoses, through their serious evolution, have anthropozoonotic characters with economic, sanitary and social implications. Infestation with arachnids diminishes considerably the quality of life of domestic animals, causing them metabolic diseases, scratching, stress, allergies and leads to the development of bacterial dermatoses. Fipronil is an acaricidal and stable remedy that lasts longer. The purpose of this study was the control of the efficacy of acaricide of the DemogedForte pharmaceutical product in order to combat the ectoparasites in cats and dogs, conditioned by the company Euro Prime Farmaceuticals LLC. The product is very effective in combating sarcoptoses and notoendrosis (98-100\%) in dogs and cats. In the treatment of otodectoses, the product demonstrated an efficacy of $99 \%$, and in demodicoses was found a result of about 90-92\%. Thus, Demoged-Forte independently, without complexs therap, demonstrated a high efficacy in the treatment of sarcoptoses, notoendrosis, otodectoses and demodicoses, ranging between 92-99\%, which confirms that we can treat animals without putting their lives in danger.

Keywords: ARACHNOSES, FIPRONIL, DIFLUBENZURON, TESTING, TREATMENT, EFFICACY.

Ectoparasites are widespread in the environment, causing a number of common parasitosis for humans and animals. The diseases that the ectoparasites produce or transmit are divided into: bladder, hives, venom, irritants, invaders, tissues, vectors, the direct pathogenic role for them being the sting [6, 8].

By their serious evolution, parasitic arachnoses have anthropozoonotic characters, having economic, health and social implications (sarcoptooses, psoroptooses, demodecoses, tick paralysis).

Arachnid infestation greatly diminishes the life quality of pets, attacking them, causing metabolic diseases, scratching, stress and allergies. By giving access to infections, ectoparasites disrupt the barrier function of the common integument leading to the development of bacterial dermatodoses. Moreover, by their role as a vector, many ectoparasites can mechanically transmit or be intermediate hosts for other pathogens (bacteria, viruses, protozoa, parasites). [3, 4]. 